\title{
Quality Testing of Air Conditioner Condensate and Its Potential in Water Conservation
}

\author{
Apurva Sabnis', Madhuvanti Kale², Manik Dhanorkar1, Sharad P. Kale ${ }^{1,3}$ \\ ${ }^{1}$ Symbiosis Centre for Waste Resource Management, Symbiosis International (Deemed) University, Pune, India \\ ${ }^{2} J$ 709, Aparna Cyberzon, Nallagandla, Hyderabad, India \\ ${ }^{3}$ Ex Bioscience Group, Bhabha Atomic Research Centre, Mumbai, India \\ Email:sharadkale@gmail.com, apurvasabnis9432@gmail.com,dyhead_scwrm@siu.edu.in,madhuvantikale@gmail.com
}

How to cite this paper: Sabnis, A., Kale, M., Dhanorkar, M. and Kale, S.P. (2020) Quality Testing of Air Conditioner Condensate and Its Potential in Water Conservation. Journal of Water Resource and Protection, 12, 93-101.

https://doi.org/10.4236/jwarp.2020.122006

Received: December 13, 2019

Accepted: January 17, 2020

Published: January 20, 2020

Copyright (c) 2020 by author(s) and Scientific Research Publishing Inc. This work is licensed under the Creative Commons Attribution International License (CC BY 4.0).

http://creativecommons.org/licenses/by/4.0/

\section{Open Access}

\begin{abstract}
A major part of world is facing water shortages today. While the world's population has grown to more than 7.75 billion, the quantity of sweet water has remained the same. The ever increasing use of water by such a large population has resulted in pollution of many water sources. The developing world where a large fraction of total world population is located faces water scarcity in a more severe manner than the developed world. The developed world has managed to control human population and preserve natural water resources more effectively. As a result of this and also due to stabilized population, they face lesser problems for water availability. Indian population stands at 1.386 billion as nowadays. The erratic monsoon rains over last few years have resulted in floods and subsequent water shortages in summer months in major part of the country. A similar situation is faced by many Asian and African countries. The means of recycling and using every possible source of water are always welcome in these countries. Since many of these countries lie in tropical or semitropical zone, the average relative humidity is more than $50 \%$ for most of the year. Changing life styles in these countries and spread of information technology based sectors have resulted in a growth spurt in air conditioning facilities. An air conditioner draws heat from surrounding air and cools the premises to desired temperature. During this process, a large amount of moisture in the atmosphere gets condensed and is drained out. There are no efforts made to recover this water in India and neighbouring countries. We have undertaken studies to check the quality of this water and see the feasibility of its use in a decentralized but effective manner. The results show that this water condensate from air conditioners is highly pure, substantial and available almost round the year. This can help in recovering millions of litres of good quality water daily. This water would find uses in industries, laboratories, households and farming. It would also create good
\end{abstract}


business opportunities.

\section{Keywords}

Water Conservation, Resource Sustainability, Air Conditioner Condensate, Relative Humidity, Distilled Water, Demineralized Water, Total Dissolved Solids (TDS), Hard Water

\section{Introduction}

The growing human population is exerting incredible stress on natural resources. Clean water, in particular, is an essential resource which is becoming more and more scarce by the year. The thickly populated developing world feels more of the pressure due to limited access to clean water. Erratic rains, aggravated by climate change, and poor storage facilities make things worse for water availability in countries like India. Thus, efforts towards conservation of water are essential for individual livelihoods and national economies alike. Here we report on a novel concept for obtaining significant amounts of pure water by utilizing the condensate generated from domestic and industrial air conditioning units. It is surprising to note that there has been no effort made so far in India and most of the developing world to tap this resource of very good quality water except for few publications in Middle East Asia. Most of this condensate water is allowed to get drained. There are only few reports available from USA where it is suggested that this water can be used for gardening (Aliso Air Inc Report, 2015) [1]. Khan and Zubaidy [2] have shown how twenty story buildings in Dubai were able to use about 78,000 $\mathrm{L}$ of condensate every month reducing the overall 0.5 $\mathrm{Kg}$ carbon dioxide emissions per $\mathrm{kWh}$ of electricity. Magrini et al. [3] have shown that in United Arab Emirates, it is possible to harvest water condensate from central air condition systems on a large scale helping conserving precious drinking water resources. Arafat Ali et al. [4] have tried to quantify the water condensate from air conditioners. They showed that quantity of condensate collected was function of time of operation, temperature difference between outside and inside where air conditioning is working and humidity difference between inside and outside environment. A shopping mall in USA could collect about $875 \mathrm{~L}$ of condensate water while a central library building could collect monthly 151,200 L of condensate from central air condition system (Guz [5]). Bryant and Ahmed [6] have shown feasibility of effectively collecting and using the condensate water from central air conditioner in an Institutional system in Doha, Qatar.

In tropical countries, air coolers and air conditioners are used in very large numbers for comfort. Air coolers use water for cooling hot, dry air while air conditioners draw heat from surrounding areas and cool the interiors to desired temperature. One metric tonne air conditioners draw 12,000 BTU (3070 Kcal) 
heat per hour. Since the relative humidity in many of these tropical and semitropical places is more than $60 \%$ for most of the year, air conditioners, while drawing the heat, condense this moisture. The water that drains from a central air conditioning unit or individual unit is condensate that has accumulated on the cooling coils within the unit. Air conditioners pull humidity out of the air and funnel the resulting water, or condensate, into a drain. The quantity of condensate which the air conditioner unit produces varies, increasing as the outdoor humidity level rises. Most modern air conditioners will produce between 15 and 70 litres of water per day depending on the capacity of the unit. A one tonne air conditioner operating for about $7-8$ hours generates up to $10 \mathrm{~L}$ of pure water which if collected aseptically, can be considered as distilled or demineralized water. This depends on the relative humidity. This condensate is typically discarded from the unit through a drain connection or left unattended and gets evaporated in the atmosphere.

We suggest that this water, being generated by condensation of atmospheric moisture, is clean and pure and can be used, if collected and stored properly, for industrial as well as domestic purposes. In this study, we have collected and analyzed condensate from domestic air conditioning units, proving the purity and suitability of the water for domestic such as household and gardening, laboratory and industrial uses such as in batteries and many other applications. It can even be used as drinking water by adding minerals in appropriate quantities. All we would need is to provide a good collection and storage system.

\section{Materials and Methods}

Sample collection: Condensate was collected from domestic air conditioning units located in Mumbai, Pune Anjar (Gujrat), Kochi, Madurai and New Mumbai. The AC unit was run continuously until $1 \mathrm{~L}$ of water was collected in second week of November 2019 in clean sterile mineral water bottles. Samples were analyzed within 24 hours of collection. They were stored in refrigerator at $8^{\circ} \mathrm{C}$ before analysis.

Water analysis: Microbiological and chemical analysis of the water was performed at National Accreditation Board for Testing and Calibration recognized Laboratories (NABL) viz. (Vipanan Laboratory, Pune, Universal Purity Testing Laboratory, Borivli, Mumbai and Tamil Nadu Water Supply and Drainage Board District Water Testing Laboratory, Madurai. Welpsun Laboratory, Anjar is an inhouse testing facility for Welspun cloth mill recognized by Gujrat Pollution Control Board.) Specifically, the water quality was measured in terms of $\mathrm{pH}$, total dissolved solids (TDS), organic carbon (T. O. C) contents, electrical conductivity, hardness, E. coli count and total coliform count. All the analytical methods are listed in Table 1 and approved by NABL, India except for total organic carbon (TOC) analysis. Though TOC analysis does not figure in IS (Indian Standard) 10,500 protocol [7] for drinking water testing, it was included here considering the overall significance of this project. TOC may be considered as an 
Table 1. Analytical procedures for various parameters in NABL accreditated labs.

\begin{tabular}{ccc}
\hline Parameter & Procedure & $\begin{array}{c}\text { Permissible limit for } \\
\text { drinking water by NABL }\end{array}$ \\
\hline TDS & IS 3025 (PART 16) [8] 1984 & $500 \mathrm{mg} / \mathrm{L}$ \\
Total Hardness & IS 3025 (PART 21) [9] 2009 & $200 \mathrm{mg} / \mathrm{L}$ \\
Conductivity & IS 3025 (PART 14) [10] 1984 & Not specified \\
E. coli & IS 15185: 2016 [11] & absent \\
Total coliforms & IS 15185: 2016 [11] & absent \\
Total organic C & IS 3025 (Part 18) [12] 1984 & Test not included in IS 10500 \\
\hline
\end{tabular}

indirect fast indicator of Biological Oxygen Demand (BOD) and Chemical Oxygen Demand (COD). Given that the condensate formation and its outflow are almost instantaneous, it is unlikely that there would be time for dissolution of any organics unless the tube through which it flows out is highly contaminated with biological growth. Table 1 lists the analytical parameters used for AC water testing and their maximum permissible limits.

\section{Results and Discussion}

Air conditioner water condensate from individual window or split air conditioners were collected from various cities in India. Table 2 shows the meterological data collected from official internet portals with respect to average relative humidity round the year in various cities in India. These figures might vary to some extent but can give us general idea about their potential. These cities account for more than $70 \%$ of the country's air conditioners. Especially the coastal cities like Mumbai, Panjim, Kochi, Bhavnagar, Chennai, Vijag, Cuttack, Bhubaneshwar, Kolkata and others (Marked yellow) where relative humidity is more than $60 \%$ throughout the year have a great potential for use of air conditioning systems. A huge water resource can be collected from these systems.

These cities with some other metro cities in Central India like Bengaluru, Hyderabad, Jaipur, Indore, Bhopal, Lucknow, Kanpur, Ahmedabad, Vadodara, Gwalior, Kanpur and smaller citied in Punjab, Madhya Pradesh, Uttar Pradesh, Jharkhand, Uttarakhand, Maharashtra, Gujrat and Karnataka contribute to more than $35 \%$ of Indian population. These cities are growing and are becoming hubs for many industrial and software activities resulting in ever increasing demands for air conditioning. The use of air conditioners has gone up considerably in last decade. The information technology sector and tourism have contributed for increased demand for the air conditioners across the country.

There are several private and government sectors where central air conditioning systems are used for 24 hours a day and 365 days a year. These point sources will contribute to recovery of very large quantities of good quality water. The air conditioned buses, cars, trucks and trains are another important sources for condensate water. While large scale collection and use of such a decentralized resource will almost certainly not be economical, the use of this water at 
Table 2. Meteorological data on average relative humidity in important Indian Cities round the year (average of last ten years 2009-2019).

\begin{tabular}{|c|c|c|c|c|c|c|c|c|c|c|c|c|}
\hline & Jan & $\mathrm{Feb}$ & Mar & April & May & June & July & Aug & Sept & Oct & Nov & Dec \\
\hline Mumbai & 65 & 65 & 65 & 65 & 65 & 80 & 85 & 85 & 80 & 75 & 65 & 60 \\
\hline Pune & 36 & 46 & 36 & 36 & 48 & 70 & 79 & 82 & 78 & 64 & 58 & 58 \\
\hline Nagpur & 54 & 43 & 30 & 24 & 27 & 55 & 77 & 80 & 74 & 61 & 55 & 56 \\
\hline Ahmedabad & 49 & 43 & 37 & 41 & 47 & 62 & 77 & 81 & 71 & 53 & 48 & 59 \\
\hline Vadodara & 45 & 45 & 35 & 35 & 50 & 65 & 80 & 75 & 70 & 60 & 55 & 55 \\
\hline Surat & 58 & 56 & 55 & 63 & 72 & 79 & 86 & 86 & 82 & 70 & 62 & 61 \\
\hline Jaipur & 53 & 54 & 42 & 30 & 32 & 52 & 75 & 82 & 72 & 51 & 50 & 61 \\
\hline Delhi & 63 & 55 & 47 & 34 & 33 & 46 & 70 & 73 & 62 & 52 & 55 & 62 \\
\hline Amritsar & 74 & 70 & 64 & 47 & 38 & 48 & 72 & 77 & 69 & 67 & 73 & 76 \\
\hline Bhatinda & 10 & 10 & 20 & 30 & 40 & 80 & 90 & 70 & 70 & 60 & 40 & 20 \\
\hline Chandigad & 60 & 55 & 40 & 35 & 35 & 45 & 65 & 70 & 65 & 40 & 40 & 60 \\
\hline Indore & 45 & 40 & 25 & 25 & 35 & 60 & 80 & 85 & 70 & 50 & 50 & 50 \\
\hline Gwalior & 10 & 15 & 20 & 20 & 40 & 80 & 80 & 80 & 60 & 30 & 20 & 20 \\
\hline Panjim & 67 & 69 & 71 & 71 & 71 & 85 & 88 & 89 & 86 & 80 & 70 & 64 \\
\hline Patna & 60 & 60 & 40 & 35 & 50 & 65 & 80 & 80 & 80 & 65 & 60 & 60 \\
\hline Raipur & 60 & 50 & 40 & 30 & 40 & 55 & 70 & 80 & 75 & 70 & 65 & 65 \\
\hline Kolkata & 65 & 60 & 60 & 65 & 70 & 80 & 80 & 85 & 85 & 75 & 70 & 70 \\
\hline Guwahati & 79 & 65 & 57 & 68 & 75 & 81 & 83 & 82 & 83 & 82 & 82 & 82 \\
\hline Shillong & 79 & 65 & 57 & 68 & 75 & 81 & 96 & 96 & 90 & 82 & 82 & 82 \\
\hline Bhubaneshwar & 60 & 61 & 63 & 66 & 66 & 74 & 83 & 85 & 83 & 76 & 66 & 60 \\
\hline Cuttack & 60 & 60 & 60 & 64 & 64 & 75 & 80 & 85 & 80 & 80 & 70 & 60 \\
\hline Hyderabad & 56 & 49 & 39 & 37 & 39 & 61 & 71 & 74 & 72 & 63 & 58 & 57 \\
\hline Vijag & 70 & 70 & 70 & 70 & 70 & 70 & 80 & 80 & 80 & 75 & 70 & 70 \\
\hline Vijaywada & 71 & 70 & 69 & 71 & 69 & 71 & 76 & 77 & 78 & 74 & 68 & 67 \\
\hline Chennai & 73 & 72 & 70 & 69 & 62 & 57 & 64 & 66 & 72 & 77 & 78 & 77 \\
\hline Bengaluru & 60 & 55 & 35 & 40 & 60 & 70 & 80 & 80 & 80 & 78 & 75 & 70 \\
\hline Manganlore & 65 & 70 & 75 & 75 & 75 & 85 & 85 & 85 & 85 & 80 & 78 & 75 \\
\hline Madurai & 35 & 35 & 40 & 80 & 75 & 55 & 55 & 55 & 65 & 80 & 80 & 50 \\
\hline Thiruanantpuram & 70 & 70 & 70 & 80 & 80 & 85 & 85 & 80 & 80 & 80 & 80 & 75 \\
\hline Ludhiana & 74 & 66 & 62 & 44 & 39 & 49 & 71 & 76 & 68 & 61 & 68 & 74 \\
\hline Dehradun & 91 & 83 & 69 & 53 & 49 & 65 & 86 & 89 & 83 & 75 & 82 & 89 \\
\hline
\end{tabular}

source for domestic and industrial purposes is easily possible. Large industrial and building-scale central HVAC systems generate much larger amounts of condensate, which can then be collected and used at source as appropriate. In many such places, air conditioner condensate is collected centrally only to be 
drained off! The present study hopefully will help in changing the mindset and systems will be evolved to collect this condensate and use it effectively.

Table 3 shows the results of analysis of water condensate samples collected from various locations in India during the month of November 2019. The theoretical collection rate as calculated using basic thermodynamic principles is included for reference. It is clear that in most tropical climates, where relative humidity is often above $60 \%$, a daily collection of up to $10 \mathrm{~L}$ liters of water is feasible from a single air conditioning unit of $1 \mathrm{MT}$ capacity and up to $25-30 \mathrm{~L}$ for 2 MT air conditioner unit. We have actually collected 40 - $50 \mathrm{~L}$ water condensate from a location in Vashi in 6 hours (New Mumbai) where 5 air conditioners of 1 MT capacity each are connected on line.

Analysis of the water quality of samples generated from domestic air conditioners is summarized in Table 3. Microbiologically all the samples were bacteria free except the sample in Kochi where it was collected from an open tank which collects air conditioner condensate centrally. Since it is an open tank, the aerial bacterial contamination is not unexpected. It is encouraging to note that none of the samples showed presence of $E$. coli which is indicator of water quality for potability. The chemical parameters like TDS, organic carbon and hardness also showed that the air conditioner condensate is extremely pure and might be comparable with distilled or demineralized water. The maximum permissible limit for TDS in drinking water as per Indian standards is $500 \mathrm{mg} / \mathrm{L}$ while the results show that it varies from 10 to $91 \mathrm{mg} / \mathrm{L}$ in these condensates. The values obtained for hardness quality also are indicative of high purity of these

Table 3. Analysis of quality of AC condensate water (1 MT unit) collected from different locations in November 2019.

\begin{tabular}{cccccccc}
\hline Sample & $\mathrm{pH}$ & $\begin{array}{c}\mathrm{TDS} \\
\mathrm{Mg} / \mathrm{L}\end{array}$ & $\begin{array}{c}\text { Conductivity } \\
\mu \mathrm{S} / \mathrm{cm}\end{array}$ & $\begin{array}{c}\text { Organic C } \\
\mathrm{Mg} / \mathrm{L}\end{array}$ & $\begin{array}{c}\text { Hardness } \\
\mathrm{Mg} / \mathrm{L}\end{array}$ & $\begin{array}{c}\text { E. coli } \\
\text { cfu }\end{array}$ & $\begin{array}{c}\text { Total coliforms } \\
\text { cfu }\end{array}$ \\
\hline Bandra & 7.00 & 30 & 66.8 & $<3$ & 12 & 0 & 0 \\
Andheri & 7.02 & 46 & 108.5 & $<3$ & 8 & 0 & 0 \\
Vashi & 6.94 & 14 & 31.2 & $<3$ & 3 & 0 & 0 \\
Govandi I & 7.00 & 41 & 20 & $<3$ & 2 & 0 & 0 \\
Govandi II & 6.95 & 91 & 20 & $<3$ & 3 & 0 & 0 \\
Goregaon & 6.95 & 34 & 71.2 & $<3$ & 12 & 0 & 0 \\
Kalina & 7.03 & 49 & 78.2 & $<3$ & 18 & 0 & 0 \\
Kharghar & 6.97 & 14 & 18 & $<3$ & 3 & 0 & 0 \\
Pune I & 6.95 & 23 & 45 & $<3$ & 2 & 0 & 0 \\
Symbiosis & 6.95 & 23 & 17 & $<3$ & 3 & 0 & 0 \\
Pune II & 6.95 & 12 & 15 & $<3$ & 3 & 0 & 0 \\
Kochi & 6.98 & 17 & 20 & $<3$ & 3 & 0 & $130^{*}$ \\
Anjar & 6.92 & 20 & 51.3 & - & 1 & - & - \\
\hline
\end{tabular}

Sample was taken from open tank where AC condensate is collected centrally. 
condensates. If a good closed loop collection system is developed, these levels can be brought to almost zero. Whatever small impurities reflected in TDS and the observed conductivity values were mainly due to contamination during collection. Since none of the air conditioner unit in India is designed to collect this condensate water aseptically and almost all of this condensate is flowing out into environment, it is expected that the drain end of the unit will not be maintained specifically for collection purpose. If the air conditioner manufacturers take up this issue seriously and design a small tank of maximum daily output capacity, it would boost the use of this very pure resource which is getting wasted.

There are few reports about fungal contaminations and bacterial infections due to their growth near outlets. The bacterium Legionella pneumophila is responsible for most cases of Legionnaires' disease. Outdoors, legionella bacteria survive in soil and water, but rarely cause infections. However, legionella bacteria can multiply in water systems made by humans, such as air conditioners [13]. In a study published in 2005, a good number of hospital infection cases were linked to contamination from AC units in India [14]. These possibilities can be eliminated if a good collection and storage system is provided along with the air conditioning unit.

\section{Conclusions}

Air conditioning units generate significant amounts of chemically and microbiologically pure water during their normal operations. This study shows the feasibility of collecting and using this water at source for both domestic and industrial purposes. Large industrial AC systems, trains and cars can also potentially bottle the condensate and convert a waste stream into a revenue source. Current AC unit designs include a drainage tube to remove the condensate. A simple water collection system can be designed and included in the unit at the time of manufacture in order to facilitate its use. There are roughly about 6 million air conditioner units active in Indian houses and establishments and the number is rising exponentially. The high purity water condensate collected from all these units will be between 50 and 100 million litres a day for most part of the year. We can no more ignore this issue and allow this precious resource to get drained. An aesthetically good looking storage tank near the air conditioner unit inside the hall would maintain the purity of this condensate and high value applications like battery or drinking water. It would certainly encourage the people to collect this condensate.

As the dual challenges of population growth and climate change stress the planet's resources and threaten livelihoods, simple, decentralized technologies will form a major part of the solution to the problem of water scarcity. Even as we collectively focus scientific and engineering resources on big, revolutionary technologies to mitigate our challenges, it is valuable to invest in easily executable technologies that can have a meaningful impact on the way the general public gets involved in solving these problems. In addition to the obvious impact on 
reducing water waste, the sociological impact of this technology will also be significant, as it will encourage more people to focus on the ideals of conservation and minimizing our environmental footprint. Ultimately, simple technologies with widespread adaptation will have the most impact on our collective efforts to survive on a crowded and climatically changing planet.

It is high time that leading manufacturers of air conditioners like Voltas, BPL, LG, Hitachi, Godrej and many others take cognizance of this study not only in India but worldwide and help in developing a good collection system for water condensate. This would also offer good business opportunities.

\section{Acknowledgements}

The authors express their deep gratitude to Dr. Ramesh Kumar (Welspun, Anjar) in collecting and analyzing samples. We are thankful to Dr. Shubhada Nayak (Vice Principal, KBP College, Vashi), Dr. Anu Appukuttam (Kochi Refineries), Dr. Varsha Kelkar, Mumbai University, Dr. Sukruta Pethe and Ms. Varsha Bapat, Andheri, Mumbai, Mr. G. T. Karnani Bandra, Shri Avinash Gavankar, Goregaon, Mumbai and Mr. Sivakumar (Madurai) for their help in collecting samples in Anjar, Vashi, Kochi, Mumbai and Madurai.

\section{Conflicts of Interest}

The authors declare no conflicts of interest regarding the publication of this paper.

\section{References}

[1] (2015) Aliso Air Report: Five Ways in Which Air Conditioning Water Can Be Recycled. https://alisoair.com/5-ways-air-conditioning-water-can-recycled/

[2] Khan, S.A. and Al Zubaidy, S.N. (2013) Conservation of Potable Water Using Chilled Water Condensate from Air Conditioning Machines in Hot and Humid Climate. International Journal of Engineering \& Technology, 3, 183-188.

[3] Magrini, A., Cattani, L., Cartesegna, M. and Magnani, L. (2017) Water Production from Air Conditioning Systems: Some Evaluations about a Sustainable Use of Resources. Sustainability, 9, 1309-325. https://doi.org/10.3390/su9081309

[4] Ali, M.A., Saifur, S. and Ali, M.A. (2018) Quantification of Condensate Water Generated from Air Conditioning System. Global Science Technology Journal, 6, 44-56.

[5] Karen, G. (2005) Condensate Water Recovery. ASHRAE Journal, 47, 54-56.

[6] Bryant, J. and Ahmed, T. (2008) Condensate Water Collection for an Institutional Building in Doha, Qatar. Proceedings of 16th Symposium on Improving Building Systems in Hot and Humid Climates, Plano, Texas, 15-17 December 2008, 15-17.

[7] IS 10500: Drinking Water Standards, Government of India. https://law.resource.org/pub/in/bis/S06/is.10500.2012.pdf

[8] IS 3025 Part 161984 Methods for Sampling and Test (Physical and Chemical) for Water and Waste Water (Amended in 1999). https://ia803008.us.archive.org/6/items/gov.in.is.3025.16.1984/is.3025.16.1984.pdf

[9] IS 3025 Part 21, 2009 Methods for Sampling and Test (Physical and Chemical) for Water and Waste Water (Hardness). 
https://ia801901.us.archive.org/6/items/gov.law.is.3025.21.2009/is.3025.21.2009.pdf

[10] IS 3925 Part 14, 1984 Methods for Sampling and Test (Physical and Chemical) for Water and Waste Water (Conductivity).

https://ia801904.us.archive.org/9/items/gov.law.is.3025.14.1984/is.3025.14.1984.pdf

[11] IS 15185, 2016 Water Quality-Detection and Enumeration of E. coli and Coliform Bacteria, Membrane Filtration Technique.

https://ia800404.us.archive.org/21/items/gov.in.is.15185.2002/is.15185.2002.pdf

[12] IS 3025 Part 18, 1984 Methods for Sampling and Test (Physical and Chemical) for Water and Waste Water-Volatile and Fixed Residues.

https://www.scribd.com/document/36550968/3025-18

[13] Legeionnair's Disease (2019)

https://www.mayoclinic.org/diseases-conditions/legionnaires-disease/symptoms-ca uses/syc-20351747

[14] Kelkar, U., Bal, A.M. and Kulkarni, S. (2005) Fungal Contamination of Air Conditioning Units in Operating Theatres in India. Journal of Hospital Infection, 50, 51-64. 